\title{
Adsorption of Fenamiphos Pesticide from Aqueous Solutions by Electrocoagulation Using Sacrificial Anodes
}

Nasser M Abu Ghalwa* and Nader B Farhat

Chemistry Department, Al-Azhar University, Gaza, Palestine

\begin{abstract}
The present study deals with removal efficiency of the pesticide fenamiphos and chemical oxygen demand (COD) from aqueous solution by electrocoagulation method. The effects of initial $\mathrm{pH}$, current density, initial pesticide concentration, salt concentration, usage of different electrolytes and temperature on the removal efficiency and COD have been investigated. The obtained results showed that fenamiphos and COD removal were $97.4 \%$ and $96.4 \%$ by using C with SS (Carbon as the anode and stainless steel as the cathode) at $60 \mathrm{~min}$ and were $90.3 \%$ and $88.2 \%$ by using SS with $\mathrm{Ti}$ (stainless steel as the anode and titanium as the cathode) at the same time. These electrodes provided a higher oxidation rate, higher current efficiency, high over potential and consume less electrical energy. The experimental data were fitted with several adsorption isotherm models to describe the electrocoagulation process. This study has been carried out to determine the feasibility of fenamiphos adsorption on carbon and stainless steel species by EC process using the Langmuir and Freundlich Isotherm. In addition, results for the fenamiphos removal kinetics at various effects show that the kinetic rates conformed to the pseudo first order kinetic model with good correlation using both electrodes.
\end{abstract}

Keywords: Electrocoagulation; Adsorption; Stainless steel; Titanium; Carbon; Fenamiphos; Pesticide; Water treatment

\section{Introduction}

Organophosphorus pesticides (OPPs) are one group of chemical pesticides now widely used in agriculture, and account for more than $36 \%$ of the total world market of chemical pesticides [1]. Fenamiphos an organophosphorus pesticide is primarily used to control nematodes in a wide range of horticultural crops and in turf [2]. This pesticide is applied at various stages of plant growth such as pre-planting, at-planting, pre and post-harvest on a variety of plants including tobacco, turf, bananas, pineapples, citrus and other fruit vines, vegetables, and grains [3]. Fenamiphos is highly toxic via the oral route, with reported LD50 values of 2 to $19 \mathrm{mg} / \mathrm{kg}$ in the rat and 56 to $100 \mathrm{mg} / \mathrm{kg}$ in guinea pigs. The inhalation toxicity of the compound is also high, with reported inhalation LC50 values in rats of 0.11 to $0.17 \mathrm{mg} / \mathrm{L}[4,5]$. Various treatment procedures have been reported for the removal of fenamiphos from water e.g. Photocatalytic [6,7], photolysis and photodegradation [8] and biodegradation [9]. In the recent years, there is an increasing interest in the development of environmentally friendly electrochemical methods to treat toxic organic pollutants in water [10]. The electrocoagulation is a simple and efficient method for the treatment of many water and wastewaters. In recent years, many investigations have been especially focused on the use of electrocoagulation owing to the increase in environmental restrictions on effluent wastewater [11,12]. EC has been successfully tested to treat various industrial water and wastewater such as potable water [13,14], food and protein wastewater [15], yeast wastewater [16], urban wastewater [17], restaurant wastewater [18,19], tar sand and oil shale wastewater [20], nitrate containing wastewater solutions [21] and arsenic containing smelter wastewater [22]. In recent studies, many pesticides such as Malathion [23], methyl parathion, atrazine and triazophos [24], malathion, imidacloprid and chlorpyrifos [25], and abamectin [26] have been treated successfully by the electrochemical methods.

The purpose of the present work is to study the effectiveness of electrocoagulation process on removing investigated fenamiphos pesticide and chemical oxygen demand (COD) in aqueous solution using different electrodes and investigate the effects of various operating parameters on the removal efficiency such as initial pesticides concentration, initial $\mathrm{pH}$, current density, electrolyte concentration, type of electrolyte, temperature and kinetic studies on the removal efficiency.

\section{Experiment}

\section{Chemicals}

The pesticide used in the present work was fenamiphos, Pesticide Solutions. Fenamiphos solutions were prepared from the commercially available pesticide, in distilled water. Fenamiphos also known as (Nemacur ${ }^{\circ}$ ), at a concentration of $400 \mathrm{~g} \mathrm{~L}^{-1}$. This concentration is the same as that used by farmers during strawberry cultivation. The properties of the fenamiphos are given in Table 1.

Sodium chloride, sodium sulfate, sodium carbonate, potassium chloride, sodium fluoride, sodium hydroxide, sulfuric acid, potassium dichromate, was of analytical grade and purchased from Merck. Distilled water was used for the preparation of solutions. Standard solutions of potassium dichromate $\left(\mathrm{K}_{2} \mathrm{Cr}_{2} \mathrm{O}_{7}\right)$, sulfuric acid $\left(\mathrm{H}_{2} \mathrm{SO}_{4}\right)$ reagent with silver sulfate $\left(\mathrm{Ag}_{2} \mathrm{SO}_{4}\right)$, Mercury sulfate $\left(\mathrm{HgSO}_{4}\right)$ and were prepared to measure the COD. A stock solution of pesticide $(1000 \mathrm{mg} / \mathrm{L})$ was prepared by dissolving an accurate quantity of the pesticide in distilled water and suitably diluted to the required initial concentrations. Different standard solutions of pesticide with concentration from 30 $150 \mathrm{mg} \mathrm{L}^{-1}$ were prepared to measure its removal at different conditions. The $\mathrm{pH}$ of the working solution was adjusted to the desired values with $0.1 \mathrm{~N} \mathrm{HCl}$ or $0.1 \mathrm{~N} \mathrm{NaOH}$.

\section{Equipments and procedures}

The electrocoagulation unit consisted of a $100 \mathrm{ml}$ electrochemical reactor with carbon with stainless steel and stainless steel with titanium

${ }^{*}$ Corresponding author: Nasser M. Abu Ghalwa, Chemistry Department, Al-Azhar University, Gaza, Palestine, Tel: 970082641884; E-mail: dr.nasser.galwa@hotmail.com

Received January 18, 2016; Accepted February 28, 2016; Published March 03, 2016

Citation: Ghalwa NMA, Farhat NB (2016) Adsorption of Fenamiphos Pesticide from Aqueous Solutions by Electrocoagulation Using Sacrificial Anodes. J Environ Anal Toxicol 6: 357. doi:10.4172/2161-0525.1000357

Copyright: (c) 2016 Ghalwa NMA, et al. This is an open-access article distributed under the terms of the Creative Commons Attribution License, which permits unrestricted use, distribution, and reproduction in any medium, provided the original author and source are credited. 
Citation: Ghalwa NMA, Farhat NB (2016) Adsorption of Fenamiphos Pesticide from Aqueous Solutions by Electrocoagulation Using Sacrificial Anodes. J Environ Anal Toxicol 6: 357. doi:10.4172/2161-0525.1000357

\begin{tabular}{|c|c|}
\hline Pesticide & Fenamiphos \\
\hline IUPAC Name & $\begin{array}{l}\text { ((RS)- } N \text {-[Ethoxy-(3-methyl 4methylsulfanylphenoxy) } \\
\text { phosphoryl]propan-2-amine }\end{array}$ \\
\hline \multicolumn{2}{|l|}{$\begin{array}{l}\text { Chemical } \\
\text { structure }\end{array}$} \\
\hline $\begin{array}{l}\text { Solubility in } \\
\text { water }\end{array}$ & $400 \mathrm{mg} / \mathrm{L}$ \\
\hline $\begin{array}{l}\text { Chemical } \\
\text { formula }\end{array}$ & $\mathrm{C}_{13} \mathrm{H}_{22} \mathrm{NO}_{3} \mathrm{PS}$ \\
\hline $\begin{array}{l}\text { Molecular } \\
\text { weight (g/mol) }\end{array}$ & $303.40 \mathrm{~g} / \mathrm{mole}$ \\
\hline$\ddot{\mathrm{e}}_{\max }$ & $249 \mathrm{~nm}$ \\
\hline
\end{tabular}

electrodes (anode and cathode) with an effective surface area of $5.4 \mathrm{~cm}^{2}$. The electrodes were $17 \mathrm{~mm} \times 10 \mathrm{~mm}$ and inter electrodes distance was 1 $\mathrm{cm}$. The electrodes were positioned vertically and parallel to each other. The current density was maintained constant by means of a precision DC power supply, model (DZ040019) EZ Digital CO. Ltd. (Korea). The pesticide concentration was determined using a double - beam UV-Vis spectrophotometer, model UV 1601 is from Shimadzu (Japan) at 249 nm. Hot Plate, model (HB502), BIBBY STERILIN LTD. (U.K.). A pH meter model AC28, TOA electronics Ltd., (Japan). Water bath model SB-650, Tokyo Kikakkai CO. Ltd., (Japan). A closed reflux titrimetric unit was used for the COD determination. Chemical Oxygen Demand (COD), HANNA instruments, Thermo reactor, model C9800 Reactor in Hungary - Europe.

\section{Analysis}

Two main parameters were measured to evaluate the electrochemical treatment efficiency, the remaining pollutant concentration and the COD. Remaining pollutants fenamiphos concentration was measured with the double-beam UV-visible spectrophotometer at $\lambda_{\max }=249 \mathrm{~nm}$ using calibration curve with standard error $\pm 0.5 \%$. The COD was determined using a closed reflux colorimetric method. The equation used to calculate the pesticide removal efficiency in the treatment experiments was:

$$
\% \mathrm{E}=\left[\frac{\mathrm{A}_{\mathrm{o}}-\mathrm{A}}{\mathrm{A}_{\mathrm{O}}}\right] \times 100
$$

Where $\mathrm{A}_{\mathrm{o}}$ and $\mathrm{A}$ are absorbance values of pesticide solutions before and after treatment with respect to their $\lambda_{\max }[11]$.

The calculation of COD removal efficiencies after electrocoagulation treatment was performed using the following formula [27].

$$
\mathrm{C}_{\mathrm{R}} \%=\left[\frac{\mathrm{C}_{\mathrm{o}}-\mathrm{C}}{\mathrm{C}_{\mathrm{o}}}\right] \times 100
$$

Where $\mathrm{C}_{0}$ and $\mathrm{C}$ are concentrations of wastewater before and after electrocoagulation

\section{Result and Discussion}

\section{Mechanism of electrocoagulation process}

In electrocoagulation process we can use variety of electrodes for the treatment of aqueous solutions, which are iron or steel, aluminum, magnesium or combination of them [28]. The possible reactions which occur during the electrocoagulation process are $[29,30]$.
At the anode:

$\mathrm{M} \rightarrow \mathrm{M}^{\mathrm{n}+}+\mathrm{ne}$

$2 \mathrm{H}_{2} \mathrm{O} \rightarrow 4 \mathrm{H}^{+}(\mathrm{aq})+\mathrm{O}_{2}(\mathrm{~g})+4 \mathrm{e}^{-}$

At the cathode:

$$
\begin{aligned}
& \mathrm{M}^{\mathrm{n}+}{ }_{(\mathrm{aq})}+\mathrm{ne}^{-} \rightarrow \mathrm{M}(\mathrm{s}) \\
& 2 \mathrm{H}_{2} \mathrm{O}(\mathrm{l})+2 \mathrm{e}^{-} \rightarrow \mathrm{H}_{2}(\mathrm{~g})+2 \mathrm{OH}^{-}{ }_{(\mathrm{aq})}
\end{aligned}
$$

Where $\mathrm{M}$ is the material used as electrode and $\mathrm{n}$ is the number of electrons. During the electrocoagulation process metal hydroxides, polyhydroxides and/or polyhydroxymetallic compounds of the electrode material will be generated. These materials contain strong affinity for dispersed particles and counter ions, which results in coagulation [29].

\section{Effect of current density}

The current density is the current per unit surface; it is a parameter that controls the anode dissolution speed on the one hand, and that of hydrogen formation on the other hand [14,31]. The influence of the variation of this parameter between $9-55 \mathrm{~mA} / \mathrm{cm}^{-2}$ has been examined on the removal efficiency of fenamiphos and COD at 60 min using (C with SS) and (SS with Ti) electrodes at initial concentration of 50 $\mathrm{mg} / \mathrm{L}, \mathrm{NaCl}$ concentration of $1 \mathrm{~g} / \mathrm{L}, \mathrm{pH}$ of 6.7 and temperature of $20^{\circ} \mathrm{C}$. Figure 1 and Table 2 indicate that a current of $18.5 \mathrm{~mA} / \mathrm{cm}^{2}$ gives fenamiphos removal efficiency of $97.4 \%$ and COD $96.4 \%$ using (C with SS) electrodes. While by using (SS with Ti) electrodes fenamiphos removal efficiency reached $90.3 \%$ and COD $88.2 \%$. From Figure 1 and Table 2 when the current density increases, the efficiency of ion

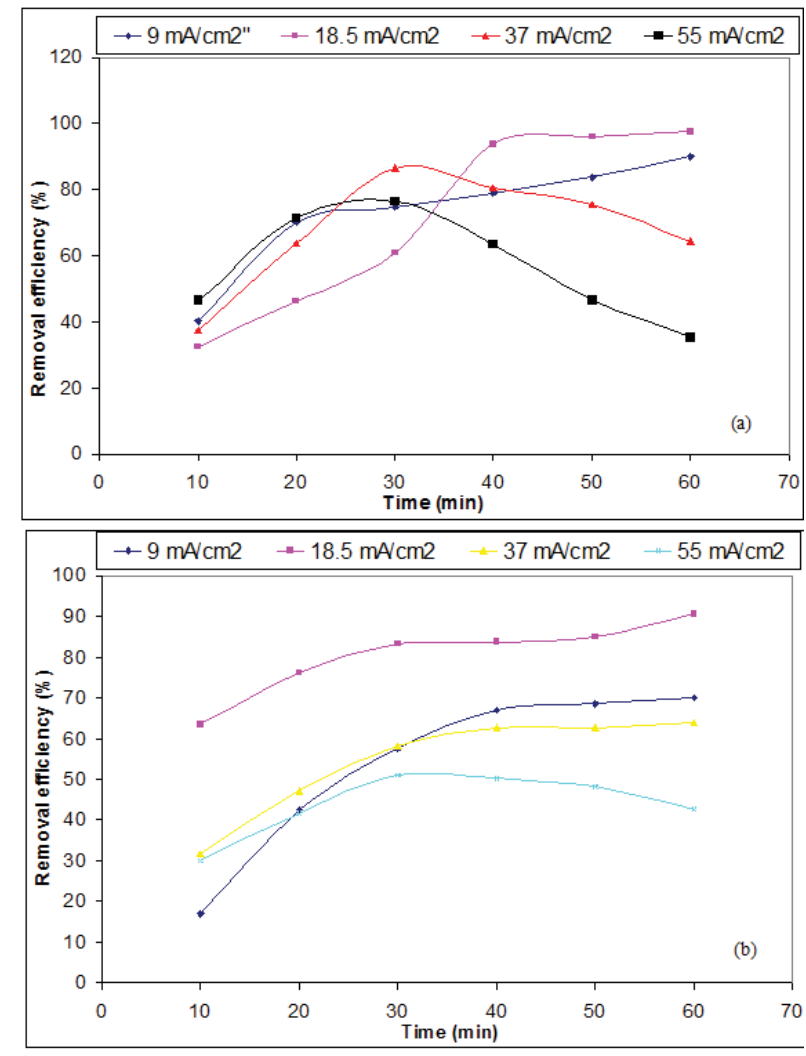

Figure 1: Effect of current density on the efficiency of fenamiphos adsorption using $\mathrm{C}$ with S.S (a) and S.S with Ti (b) electrodes. 


\begin{tabular}{|c|c|c|c|c|c|c|c|c|c|c|}
\hline \multirow[b]{2}{*}{ Current density $\left(\mathrm{mA} / \mathrm{cm}^{2}\right)$} & \multicolumn{5}{|c|}{ C with S.S(a) } & \multicolumn{5}{|c|}{ S.S with $\mathrm{Ti}(\mathrm{b})$} \\
\hline & 9 & 18.5 & 37 & 55 & - & 9 & 18.5 & 37 & 55 & - \\
\hline COD $(\%)$ & 88.2 & 96.4 & 63.5 & 58.8 & - & 82.3 & 88.2 & 80 & 63.5 & - \\
\hline $\mathrm{pH}$ & 2 & 4.5 & 6.7 & 8 & 10 & 2 & 4.5 & 6.7 & 8 & 10 \\
\hline COD (\%) & 76.4 & 88.2 & 96.4 & 82.3 & 72.9 & 47 & 67.5 & 88.2 & 89.4 & 88.2 \\
\hline Electrolyte & $\mathrm{KCl}$ & $\mathrm{Na}_{2} \mathrm{CO}_{3}$ & $\mathrm{NaCl}$ & $\mathrm{Na}_{2} \mathrm{SO}_{4}$ & $\mathrm{NaF}$ & $\mathrm{KCl}$ & $\mathrm{Na}_{2} \mathrm{CO}_{3}$ & $\mathrm{NaCl}$ & $\mathrm{Na}_{2} \mathrm{SO}_{4}$ & - \\
\hline COD (\%) & 80.5 & 53.5 & 96.4 & 68 & 32.1 & 84.7 & 70.5 & 88.2 & 70.5 & - \\
\hline$[\mathrm{NaCl}](\mathrm{g} / \mathrm{L})$ & 0.5 & 1 & 1.5 & 2 & - & 0.5 & 1 & 1.5 & 2 & - \\
\hline COD (\%) & 82.3 & 96.4 & 74.1 & 74.1 & - & 72.9 & 88.2 & 70.5 & 43.5 & - \\
\hline [PESTICIDE] (mg/L) & 30 & 50 & 100 & 150 & - & 30 & 50 & 100 & 150 & - \\
\hline COD (\%) & 88.2 & 96.4 & 61.1 & 49.4 & - & 91.7 & 88.5 & 35.2 & 20 & - \\
\hline Temperature & \multirow{2}{*}{10} & \multirow{2}{*}{20} & \multirow{2}{*}{30} & \multirow{2}{*}{40} & \multirow{2}{*}{-} & \multirow{2}{*}{10} & \multirow{2}{*}{20} & \multirow{2}{*}{30} & \multirow{2}{*}{40} & \multirow{2}{*}{-} \\
\hline$\left({ }^{\circ} \mathrm{C}\right)$ & & & & & & & & & & \\
\hline COD (\%) & 94.1 & 96.4 & $75 . .2$ & 74.1 & - & 83.5 & 88.2 & 88.2 & 64.7 & - \\
\hline
\end{tabular}

Table 2: Effect of current density, $\mathrm{pH}$, type of electrolyte, concentration and temperature on the efficiency of COD removal for fenamiphos electrolyte, pesticide using $\mathrm{C}$ with S.S (a) concentration and S.S with Ti (b) electrodes.

production on the anode and cathode increases. Therefore, there is an increase in floc production in the solution and hence an improvement in the efficiency of pesticides removal. The increase of coagulant and bubbles generation rate lead to the increase number of $\mathrm{H}_{2}$ bubbles and decrease their size with increasing current density resulting in a faster adsorption of pesticides [32,33].

\section{Effect of electrolyte Concentration}

The supporting electrolyte increases solution conductivity; hence it influences the generated current and energy consumption of the process. Many researchers have found $\mathrm{NaCl}$ as the best supporting electrolyte [34]. The effect of $\mathrm{NaCl}$ on removal efficiency of fenamiphos and COD was examined at 60 min using (C with SS) electrodes and (SS with $\mathrm{Ti}$ ) electrodes at initial concentration of $50 \mathrm{mg} / \mathrm{L}$, current density of $18.5, \mathrm{pH}$ of 6.7 and temperature of $20^{\circ} \mathrm{C}$. Figure 2 and Table 2 shows the maximum removal efficiency of fenamiphos and COD was obtained at $1 \mathrm{~g} / \mathrm{L} \mathrm{NaCl}$ concentrations. However, with the increasing in $\mathrm{NaCl}$ concentration $>1 \mathrm{~g} / \mathrm{L}$ the removal efficiency decreased due to when the increase in $\mathrm{NaCl}$ concentration greater than $1 \mathrm{~g} / \mathrm{L}$, the removal efficiency decreased. It can be attributed that at a constant voltage with increasing of electrolyte concentration, conductivity of pesticide solution increases and resistance decreases, so the passed current increases and the produced amount of metallic hydroxide. This leads to a reduction of the oxide layer and an enhancement of the anodic dissolution of the electrode material and the pesticide adsorption increases $[35,36]$.

\section{Effect of $\mathrm{pH}$}

The influent $\mathrm{pH}$ is one of the important factors in affecting the performance of electrochemical process [14]. Experiments were carried out to evaluate the effect of $\mathrm{pH}$, using solutions containing a sample with an initial $\mathrm{pH}$ varying in the range (2-10) at a current density of $18.5 \mathrm{~mA} / \mathrm{cm}^{2}$, initial concentration of $50 \mathrm{mg} \mathrm{L}^{-1}$, inter electrode distance of $1 \mathrm{~cm}, \mathrm{NaCl}$ concentration of $1 \mathrm{~g} \mathrm{~L}^{-1}$ and temperature of $20^{\circ} \mathrm{C}$. Figure 3 and Table 2 show the pesticide removal efficiency and $\mathrm{COD}$ as a function of $\mathrm{pH}$. The removal efficiency of the pesticide and COD are high in neutral medium ( $\mathrm{pH}$ 6.7), meanwhile, in acidic and basic medium are low. The decrease of adsorption when the $\mathrm{pH}$ is higher than 9, and more acidic was observed by many investigators $[37,38]$ and was attributed to an amphoteric behavior of $\mathrm{M}(\mathrm{OH})_{3}$ which leads to soluble metal cations (at acidic $\mathrm{pH}$ ) and to monomeric anions (at alkaline $\mathrm{pH}$ ).

\section{Effect of initial pesticide concentration}

Effect of the initial concentration of fenamiphos in EC cell was investigated in the range of 30 to $150 \mathrm{mg} / \mathrm{L}$ using (C with SS) and (SS with $\mathrm{Ti}$ ) at a current density of $18.5 \mathrm{~mA} / \mathrm{cm}^{2}, \mathrm{pH}$ of 6.7 , inter electrode distance of $1 \mathrm{~cm}, \mathrm{NaCl}$ concentration of $1 \mathrm{~g} \mathrm{~L}^{-1}$ and temperature of $20^{\circ} \mathrm{C}$. From Figure 4 and Table 2 it may be seen that increasing initial pesticide concentration results in decreasing the adsorption because the amount of produced flocs is insufficient to adsorb all pesticide molecules, therefore pesticide and COD removal decreases. The maximum removal was obtained at initial concentration $50 \mathrm{mg} / \mathrm{L}$.

\section{Effect of temperature}

In the present work, effect of temperature from 10 to $40^{\circ} \mathrm{C}$ has been studied for the removal efficiency of fenamiphos and COD as shown Figure 5 and Table 2 at initial concentration of $50 \mathrm{mg} / \mathrm{L}$, current density of $18.5, \mathrm{pH}$ of 6.7 and $\mathrm{NaCl}$ concentration of $1 \mathrm{~g} / \mathrm{L}$. Figure 5 indicate that the efficiency removal and COD were optimum at $20^{\circ} \mathrm{C}$. However, with increasing temperature $>20^{\circ} \mathrm{C}$ the removal efficiency and COD decrease. Higher temperature value $\left(40^{\circ} \mathrm{C}\right)$ the pesticide removal and COD \% dropped to lower values. More dropping occur at $50^{\circ} \mathrm{C}$ using the whole electrodes. However, it should be noted that the operation of electrocoagulation process at higher temperature significantly reduced electrical energy consumption [39]. When the temperature was over than $60^{\circ} \mathrm{C}$, the current efficiency began to decrease. In this case, the volume of colloid $\mathrm{M}(\mathrm{OH})$ will decrease and pore production on the metal anode well be closed [40].

\section{Effect of the electrolyte type}

Figure 6 and Table 2 explain the effect of electrolyte type on the removal efficiency of fenamiphos and COD at $60 \mathrm{~min}$ using (C with SS) and (SS with Ti) at a current density of $18.5 \mathrm{~mA} / \mathrm{cm}^{2}, \mathrm{pH}$ of 6.7 ; inter electrode distance of $1 \mathrm{~cm}$ and temperature of $20^{\circ} \mathrm{C}$. In the presence of different supporting electrolytes including $\mathrm{NaCl}, \mathrm{KCl}, \mathrm{Na}_{2} \mathrm{SO}_{4}$ and $\mathrm{Na}_{2} \mathrm{CO}_{3}$, According to Figure 6, the pesticide removal at $\mathrm{NaCl}$, is better than $\mathrm{KCl}, \mathrm{Na}_{2} \mathrm{CO}_{3}$ and $\mathrm{Na}_{2} \mathrm{SO}_{4}$. These results may be Due to formation of hypochlorite $\left(\mathrm{OCl}^{-}\right)$and hypochlorous acid $(\mathrm{HOCl})$. This behavior may be due to the small ionic size of $\mathrm{Na}^{+}$which increases the ion mobilities and the loss ability of $\mathrm{Cl}^{-}$ion. But in the other electrolytes such as $\mathrm{Na}_{2} \mathrm{CO}_{3}, \mathrm{Na}_{2} \mathrm{SO}_{4}$ and $\mathrm{NaF}$ which do not contain chloride ions, the removal pesticide and COD efficiency dropped. $\mathrm{Na}_{2} \mathrm{SO}_{4}$ and $\mathrm{NaF}$ 


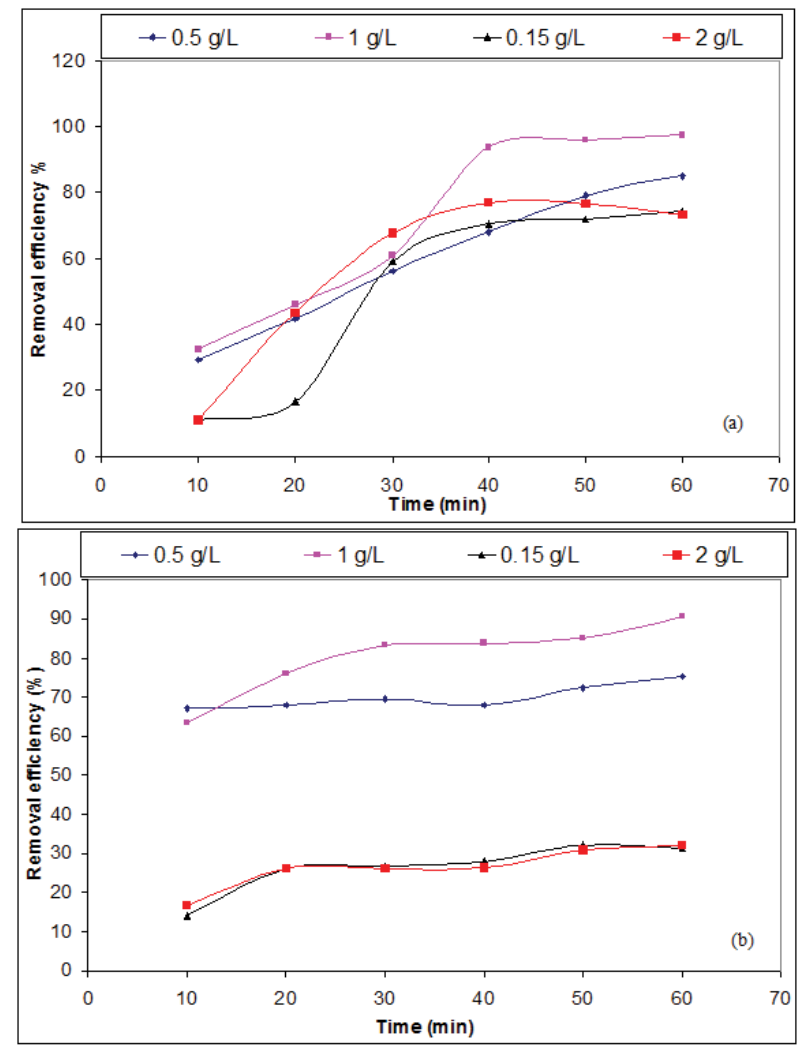

Figure 2: Effect of electrolyte concentration on the efficiency of fenamiphos adsorption using $\mathrm{C}$ with S.S (a) and S.S with $\mathrm{Ti}(\mathrm{b})$ electrodes.

electrolytes showed the least efficiency in the degradation of pollutant. This may be attributed to the formation of an adherent film on the anode surface which poisons the electrode surface. Also, these electrolytes do not contain chloride ions $\left(\mathrm{Cl}^{-}\right)$in their structures and may form stable intermediate species that could not be oxidized by direct electrolysis. These observations were also confirmed in other study [41].

\section{Adsorption data}

Kinetic studies: Figure 7 display the removal of fenamiphos exhibited pseudo first order with good correlation coefficients $(>0.96)$ using C with SS electrodes and (>0.95) using SS with Ti electrodes according to equation (7).

$$
\ln \frac{\mathrm{A}}{\mathrm{A}_{\mathrm{O}}}=-\mathrm{kt}
$$

The values of rate constants at optimum condition and reaction time were 0.0295 and $0.01 \mathrm{~mol}^{-1}$ using $\mathrm{C}$ with SS and SS with Ti electrodes respectively. Results show that the removal rate using $\mathrm{C}$ with SS electrode was higher than the removal rate using SS with $\mathrm{Ti}$ electrodes.

Isotherm modeling: The purpose of the sorption isotherms is to reveal the specific relation between the equilibrium concentration of adsorbate in the bulk and the adsorbed amount at the surface. The isotherm results fenamiphos at a constant temperature of $20^{\circ} \mathrm{C}$ were analyzed using four important isotherms including the Langmuir and Freundlich, isotherm models (Figures 8 and 9).

Langmuir isotherm: The Langmuir isotherm model was developed to represent chemisorptions at a set of well-defined localized adsorption sites with the same adsorption energy, independent of the surface coverage, and with no interaction between adsorbed molecules. This model assumes a monolayer deposition on a surface with a finite number of identical sites. The linearized form of Langmuir adsorption isotherm model is [42].

$$
\mathrm{C}_{\mathrm{e}} / \mathbf{q}_{\mathrm{e}}=1 / \mathbf{q}_{\mathrm{m}} \mathbf{b}+\left\lceil\mathrm{C}_{\mathrm{e}} / \mathbf{q}_{\mathrm{m}}\right.
$$

Where qe $(\mathrm{mg} / \mathrm{g})$ is amount adsorbed at equilibrium, Ce $(\mathrm{mg} / \mathrm{L})$ equilibrium concentration, $\mathrm{qm}$ is the Langmuir constant representing maximum monolayer adsorption capacity, and $\mathrm{b}$ is the Langmuir constant related to energy of adsorption

Freundlich isotherm: The Freundlich adsorption isotherm model includes considerations of surface heterogeneity and exponential distribution of the active sites and their energies. The isotherm is adopted to describe reversible adsorption and is not restricted to monolayer formation. This isotherm typically fits the experimental data over a wide range of concentrations. The linearized and logarithmic expression of the Freundlich model is [43]

$$
\log \mathrm{q}_{\mathrm{e}}=\log \mathrm{k}_{\mathrm{f}}^{\dagger}+\mathrm{n} \log \mathrm{Ce}
$$

where $\mathrm{kf}(\mathrm{mg} / \mathrm{g})$ and $\mathrm{n}$ (dimensionless) are constants that account for all factors affecting the adsorption process, such as the adsorption capacity and intensity. The Freundlich constants $\mathrm{K}_{\mathrm{f}}$ and $\mathrm{n}$ are determined from the intercept and slope, respectively, of the linear plot of $\log$ qe versus $\log$ Ce. Adsorption isotherms were obtained in terms of equations (8) and (9) by using experimental adsorption results in these equations. The values $\mathrm{q}_{\mathrm{m}}, \mathrm{b}, \mathrm{K}_{F}, \mathrm{R}_{L}$ and $\mathrm{n}$ are summarized in Table 3.

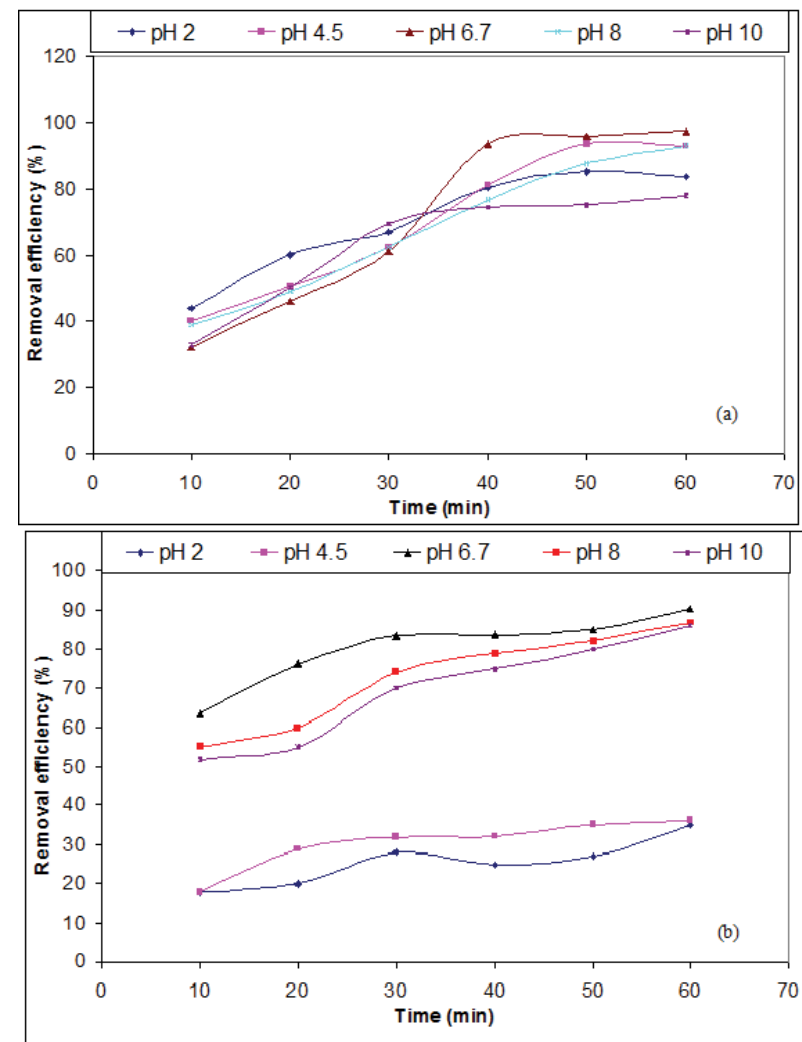

Figure 3: Effect of $\mathrm{pH}$ on the efficiency of fenamiphos adsorption using $\mathrm{C}$ with S.S (a) and S.S with Ti (b) electrodes. 
Citation: Ghalwa NMA, Farhat NB (2016) Adsorption of Fenamiphos Pesticide from Aqueous Solutions by Electrocoagulation Using Sacrificial Anodes. J Environ Anal Toxicol 6: 357. doi:10.4172/2161-0525.1000357

Page 5 of 8

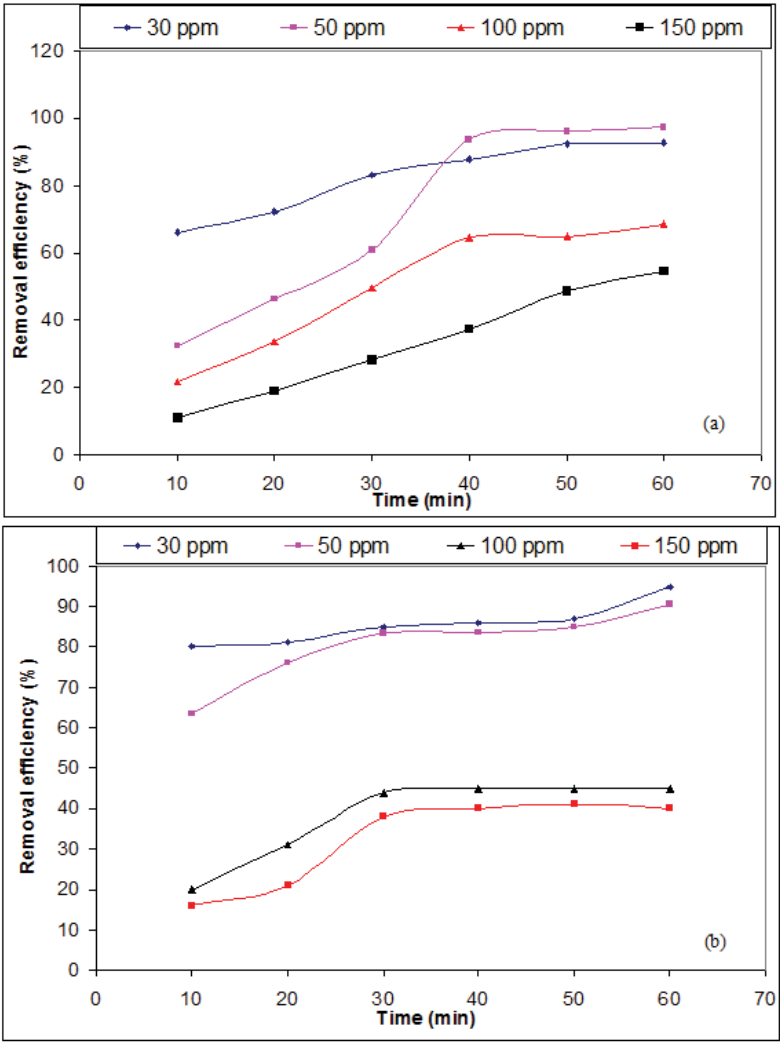

Figure 4: Effect of initial concentration on the efficiency of fenamiphos adsorption using $\mathrm{C}$ with S.S (a) and S.S with $\mathrm{Ti}$ (b) electrodes.

The essential features of the Langmuir isotherm may be expressed in terms of equilibrium parameter $\mathrm{R}_{\mathrm{L}}$, which is a dimensionless constant referred to as separation factor or equilibrium parameter [44].

$$
\mathrm{R}_{\mathrm{L}}=1 / 1+\mathrm{bC}_{\mathrm{e}}
$$

where $R_{L}$ is the equilibrium constant and indicates the type of adsorption, $\mathrm{b}$ is the Langmuir constant. $\mathrm{C}_{e}$ is initial concentration of fenamiphos solution. The $\mathrm{R}_{\mathrm{L}}$ values between 0 and 1 indicate the favorable adsorption.

It is obtained from $\mathrm{R}^{2}$ values that the equilibrium data of the system was well explained by the Langmuir model when compared to the Freundlich model. By comparing results listed in Table 3, it is clear that equilibrium data fit Langmuir and Freundlich models. Correlation coefficient of Langmuir model is higher than that of Freundlich, which means that Langmuir sorption isotherm more accurately describe the sorption of fenamiphos pesticide adsorption on the coagulant formed.

\section{Electrical Energy Consumption and Electrode Consumption}

In order to assist in assessing the economic feasibility of electrocoagulation in comparison with other techniques, the energy consumption and metal consumption were calculated as follows.

a) In an electrochemical process, the most important economical parameter is energy consumption $\mathrm{E}\left(\mathrm{kWh} / \mathrm{m}^{3}\right)[45,46]$. This parameter is calculated from the following expression:

$\mathrm{E}=\mathrm{I} \mathrm{V}_{\mathrm{t}} /$ volume $\times 1000$

where $\mathrm{V}, \mathrm{I}$ and $\mathrm{t}$ stand for average voltage of the EC system (V), electrical current intensity (A) and reaction time (h), respectively.

(For C with SS electrodes) $\mathrm{E}=1.93 \times 0.0185 \times 1 / 1 \times 10^{-4} \times 1000=$ $0.356 \mathrm{kWh} / \mathrm{m}^{3}$

(For SS with Ti electrodes) $\mathrm{E}=1.1851 \times .01851 \times 1 / 1 \times 10^{-4} \times 1000$ $=0.2194 \mathrm{kWh} / \mathrm{m}^{3}$

b) The electrode consumption can be estimated according to Faraday's law and the amount of coagulant generated can be estimated stoichiometrically [47].

$\mathrm{W}=\mathrm{I} \mathrm{T} \mathrm{M} / \mathrm{Z} \times \mathrm{F}$

Where W: the amount of the electrode dissolved (g), I: the current intensity (A), t: the time (seconds), M: the relative molar mass of the electrode, $\mathrm{z}$ : the number of electrons in the redox reaction, and $\mathrm{F}$ : Faraday's constant ( 96500 coulombs).

\section{Comparison with Other Method}

\begin{tabular}{|c|c|c|c|}
\hline Isotherm & $\mathrm{R}^{2}$ & Constnt & Value \\
\hline Langmuir & 0.98 & $q_{m}(\mathrm{mg} / \mathrm{g})$ & 74.6 \\
\hline & & $\mathbf{b}(\mathrm{L} / \mathrm{mg})$ & 67 \\
\hline Freundlich & 0.96 & $\mathrm{R}_{\mathrm{L}}$ & 0.0022 \\
\hline & & $\mathrm{K}_{\mathrm{F}}(\mathrm{mg} / \mathrm{g})$ & 50.1 \\
\hline & & $\mathrm{n}$ & 1.115 \\
\hline
\end{tabular}

Table 3: Parameters of Langmuir and Freundlichr isotherm constants and correlation coefficients using $\mathrm{C}$ with SS electrodes.
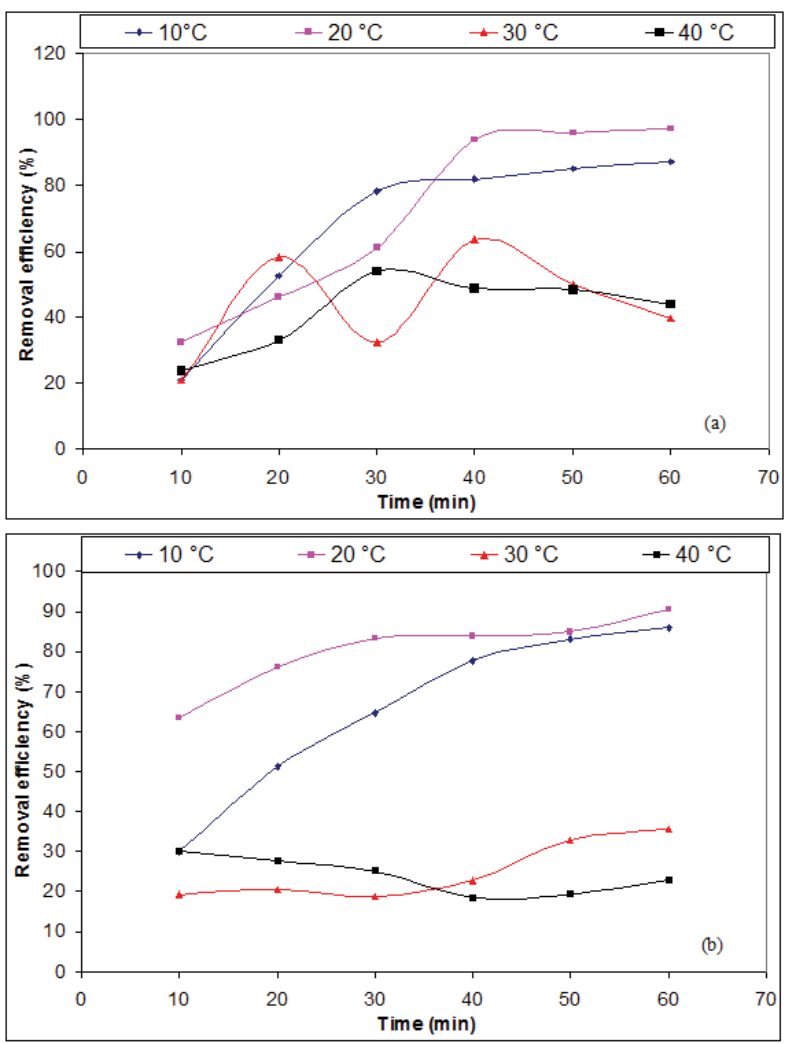

Figure 5: Effect of temperature on the efficiency of fenamiphos adsorption using $\mathrm{C}$ with S.S (a) and S.S with $\mathrm{Ti}(\mathrm{b})$ electrodes. 

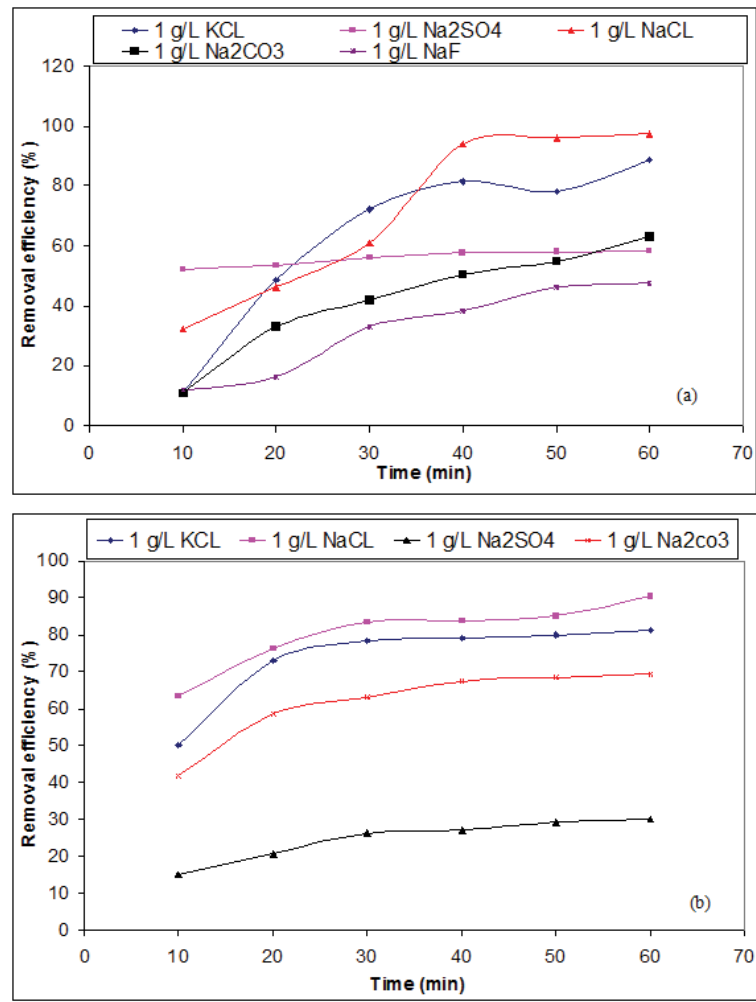

Figure 6: Effect of type of electrolyte on the efficiency of fenamiphos adsorption using $\mathrm{C}$ with S.S (a) and S.S with Ti (b) electrodes.

\begin{tabular}{|c|c|c|c|}
\hline Type of degradation & Reference & Removal \% & Time \\
\hline Photocatalytic & Fenoll et al. [6] & $100 \%$ & $240 \mathrm{~min}$ \\
\hline $\begin{array}{c}\text { Photolysis and } \\
\text { photodegradation }\end{array}$ & El Yadini et al. [8] & $100 \%$ & $180 \mathrm{~min}$ \\
\hline photocatalytic & El Yadini et al. [7] & $100 \%$ & $180 \mathrm{~min}$ \\
\hline Electrocoagulation & $\begin{array}{c}\text { This study using } \\
\text { (C with S.S }\end{array}$ & $97 \%$ & $60 \mathrm{~min}$ \\
\hline Electrocoagulation & $\begin{array}{c}\text { This study using } \\
\text { (S.S with Ti } \\
\text { electrodes) }\end{array}$ & $90.30 \%$ & $60 \mathrm{~min}$ \\
\hline
\end{tabular}

Table 4: Comparison between the Electrocoagulation methods for removal of fenamiphos with other methods.

The percentages of degradation for each method using in literature and the electrochemical method in this work were represented in the Table 4 . It is clear that the electrochemical degradation is the best.

\section{Conclusion}

The present study attempted to investigate the applicability of an electrocoagulation method in the treatment of fenamiphos pesticide in aqueous solutions. The effects of initial $\mathrm{pH}$, initial pesticides concentration, current density, type of electrolyte, salt concentration, and temperature were investigated on removal efficiency and COD. The following conclusions are drawn up based on the results:

-Electrocoagulation is a fast, effective, and clean process to remove of pesticides from aqueous solution.

- The equilibrium adsorption behavior is analyzed by fitting the isotherm models of Langmuir and Freundlich. It was noted that the Langmuir model (0.98) is higher than that of Freundlich (0.96) using $\mathrm{C}$ with SS electrodes.
-Adsorption kinetics of electrocoagulants is analyzed using first kinetic models with value $(>0.96)$ using $\mathrm{C}$ with SS electrodes and $(>0.95)$ using SS with Ti electrodes

-The electrodes arrangement of C with SS and SS with Ti as the anode-cathode achieved that the best efficacy in fenamiphos and COD removal during the EC to reach $97.4 \%$ and $96.4 \%$ by using (C with SS) electrodes at $60 \mathrm{~min}$ and were $90.3 \%$ and $88.2 \%$ by using (SS with $\mathrm{Ti}$ ) electrodes at the same time at typical operating conditions: an initial $\mathrm{pH}$ of 6.7 , initial pesticide concentration of $50 \mathrm{mg} / \mathrm{L}$, current density $18.5 \mathrm{~mA} /$ $\mathrm{cm}^{2}$, salt concentration of $1 \mathrm{~g} / \mathrm{L}$ and temperature of $20^{\circ} \mathrm{C}$.

-It is clear that our results were better than other method in literature.
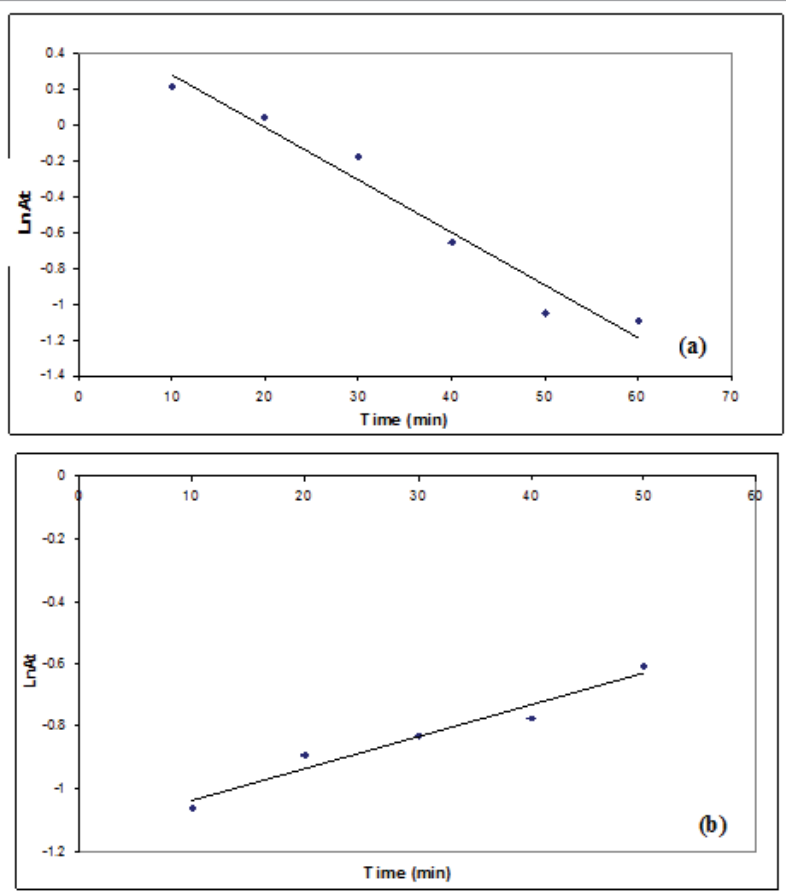

Figure 7: Relation between $\mathrm{Ln} \mathrm{A}_{\mathrm{t}}$ against the time for fenamiphos adsorption using $\mathrm{C}$ with S.S (a) and S.S with $\mathrm{Ti}$ (b) electrodes.

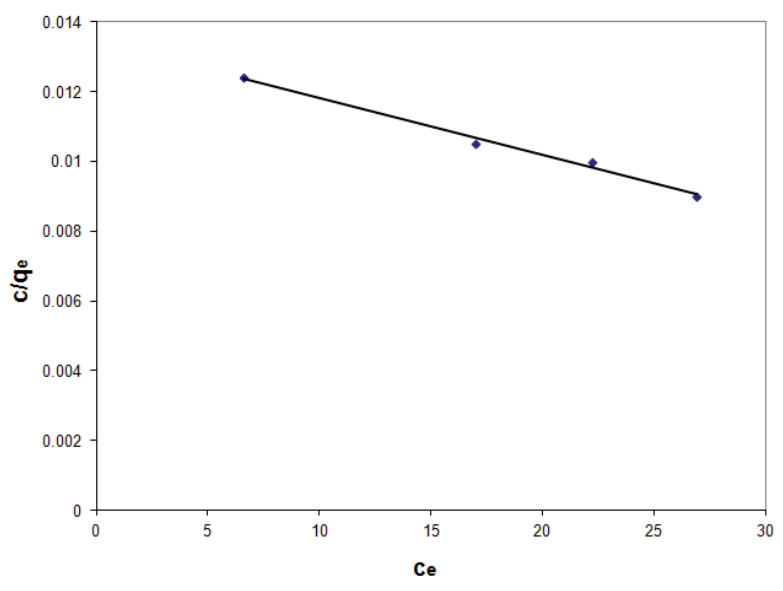

Figure 8: Langmuir plot (Ce/qe) vs. (Ce) for fenamiphos adsorption using C with S.S electrodes. 
Citation: Ghalwa NMA, Farhat NB (2016) Adsorption of Fenamiphos Pesticide from Aqueous Solutions by Electrocoagulation Using Sacrificial Anodes. J Environ Anal Toxicol 6: 357. doi:10.4172/2161-0525.1000357

Page 7 of 8

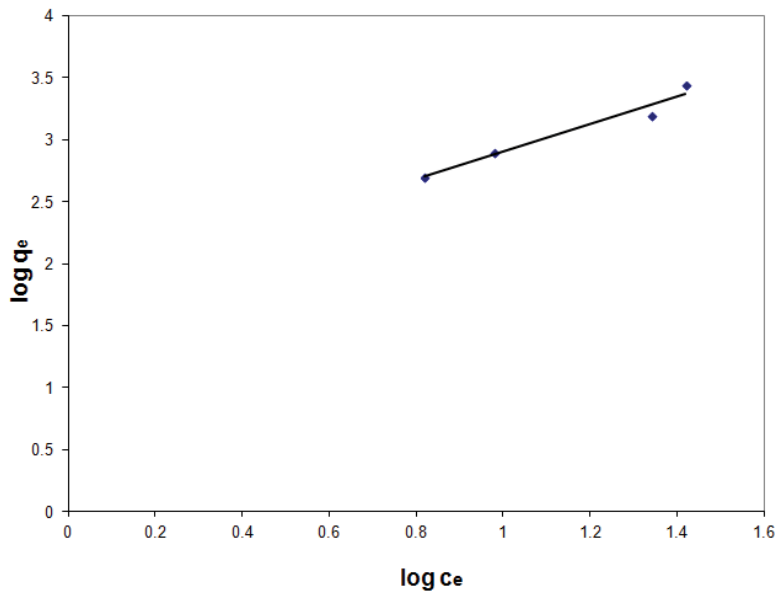

Figure 9: Freundlich plot (log qe vs. log Ce) for fenamiphos adsorption using C with S.S electrodes.

- The results were concludes that the electrode material play an important role in electrocoagulation method for treatment of pesticides in aqueous solution.

\section{References}

1. Singh BK, Walker A (2006) Microbial degradation of organophosphorus compounds. FEMS Microbiol Rev 30: 428-471.

2. Roberts T, Hutson D (1998) In: Part One: Herbicides and Plant Growth Regulators, The Royal Society of Chemistry, Cambridge, UK 91.

3. Kamrin A, Michael (1997) Pesticide profile: Toxicity environmental impact and fate Boca Raton: CRC Press LLC, 676.

4. US Public Health Service (1995) Hazardous Substance Data Bank. Washington DC, 5-9.

5. Kidd H, James DR (1991) The Agrochemicals Handbook $3^{\text {rd }}$ (Edn) Royal Society of Chemistry Information Services, Cambridge, UK 5-14.

6. Fenoll J, Hellin P, Martinez CM, Flores P, Navarro S (2012) Semiconductor oxides-sensitized photodegradation of fenamiphos in leaching water under natural sunlight. Applied Catalysis B: Environmental 115-116: 31-37.

7. El Yadini A, Saufi H, Dunlop PSM, Anthony Byrne J, El Azzouzi M, et al (2014) Supported $\mathrm{TiO}_{2}$ on Borosilicate Glass Plates for Efficient Photocatalytic Degradation of Fenamiphos. Journal of Catalysts 2014: 2-8.

8. El Yadini A, Marouane B, Ahmido A, Dunlop P, Byrne JA, et al. (2013) Photolysis and photodegradation of Fenamiphos insecticide by using slurry and supported $\mathrm{TiO}_{2}$. J Mater Environ Sci 973-980.

9. Singh BK, Walker A, Morgan JA, Wright DJ (2003) Role of soil pH in the development of enhanced biodegradation of fenamiphos. Appl Environ Microbiol 69: 7035-7043.

10. Pozzo D, Merli AC, Sirés I, Garrido JA, Rodríguez RM, et al. (2005) Remova of the herbicide amitrole from water by anodic oxidation and electro-Fenton. Environ Chem Lett 3: 7-11.

11. Mollah MY, Schennach R, Parga JR, Cocke DL (2001) Electrocoagulation (EC)--science and applications. J Hazard Mater 84: 29-41.

12. Lin SH, Shyu CT, Sun MC (1998) Saline wastewater treatment by electrochemical method. Water Res 32: 1059-1066.

13. Matteson MJ, Dobson RL, Glenn Jr RW, Kukunoor NS, Waits III WH, et al (1995) Electrocoagulation and separation of aqueous suspensions of ultrafine particles. Coll Surf A: Physicochem Eng Aspects 104: 101-109.

14. Chen X, Chen G, Yue PL (2000) Separation of pollutants from restauran wastewater by electrocoagulation. Sep Purif Technol 19: 65-76.

15. Beck EC, Giannini AP, Ramirez ER (1974) Electrocoagulation clarifies food wastewater. Food Technol 22: 18-19.

16. Khristoskova S (1984) Possibility of purification and decoloring wastewater from the yeast industry by electrocoagulation. Nauchni Tr-Plovdski Univ (Bulg) 22: $177-185$

17. Pouet MF, Grasmick A (1995) Urban wastewater treatment by electrocoagulation and flotation. Water Sci Technol 31: 275-283.

18. Chen G, Chen X, Yue PL (2000) Electrocoagulation and electroflotation of restaurant wastewater. J Environ Eng 126: 858-863.

19. Vik EA, Carlos DA, Eikum AS, Gjessing ET (1984) Electrocoagulation of potable water. Water Res 18: 1355-1360.

20. Renk RR (1988) Electrocoagulation of tar sand and oil shale wastewater. Energy Prog 8: 205-208.

21. Koparal AS, Oğütveren UB (2002) Removal of nitrate from water by electroreduction and electrocoagulation. J Hazard Mater 89: 83-94.

22. Balasubramanian N, Madhavan K (2001) Arsenic removal from industrial effluent through electrocoagulation. Chem Eng Technol 24: 519-521.

23. Behloul M, Grib H, Drouiche N, Abdi N, Lounici H, et al. (2013) Removal of Malathion Pesticide from Polluted Solutions by Electrocoagulation: Modeling of Experimental Results using Response Surface Methodology. Separation Science and Technology 48: 664-672.

24. Babu BR, Meera KMS, Venkatesan P (2011) Removal of pesticides from wastewater by electrochemical methods A comparative approach. Sustain Environ Res 21: 401-406.

25. Abdel-Gawad S, Baraka AM, Omran KA, Mokhtar MM (2012) Removal of Some Pesticides from the Simulated Waste Water by Electrocoagulation Method Using Iron Electrodes. Int J Electrochem Sci 7: 6654- 6665.

26. Nasser Ghalwa MA, Farhat NB (2015) Removal of Abamectin Pesticide by Electrocoagulation Process Using Stainless Steel and Iron Electrodes. J Environ Anal Chem 2: 4.

27. Carneiro PA, Fugivara CS, Nogueira FP, Boralle N, Zanoni VB (2003) A Comparative on Chemical and Electrochemical Degradation of Reactive Blue 4 Dye. Portugaliae Electrochimica Acta 21: 49-67.

28. Vasudevan S, Lakshmi J, Sozhan G (2009) Studies on the removal of iron from drinking water by electrocoagulation a clean process. Clean $37: 45-51$.

29. Mollah MY, Morkovsky P, Gomes JA, Kesmez M, Parga J, et al. (2004) Fundamentals, present and future perspectives of electrocoagulation. J Hazard Mater 114: 199-210.

30. Moreno CHA, Cocke DL, Gomes JAG, Morkovsky P, Parga JR, et al. (2009) Electrochemical reactions for electrocoagulation using iron electrodes. Ind Eng Chem Res 48: 2275-2282.

31. Tchinda AJ, Ngameni E, Walcarius A (2006) Thiol functionalized clay heterostructures (PCHs) deposited as thin films on carbon electrode: towards mercury(II) sensing. Sens Actuator 121: 113-123.

32. Golder AK, Samanta AN, Ray S (2007) Removal of trivalent chromium by electrocoagulation. Sep Purif Technol 5: 33-41.

33. Daneshvar N, Sorkhabi HA, Tizpar A (2003) Decolorization of orange II by electrocoagulation method. Sep Purif Technol 31: 153-162.

34. Daneshvar N, Khataee AR, Amani Ghadim AR, Rasoulifard MH (2007) Decolorization of C.I. Acid Yellow 23 solution by electrocoagulation process: investigation of operational parameters and evaluation of specific electrical energy consumption (Energy SEEC). J Hazard Mater 148: 566-572.

35. Chou WL (2010) Removal and adsorption characteristics of polyvinyl alcoho from aqueous solutions using electrocoagulation. J Hazard Mater 177: 842850 .

36. Dalvand A, Gholami M, Joneidi A, Mahmoodi NM (2011) Dye Removal, Consumption and Operating Cost of Electrocoagulation of Textile Wastewater as a Clean Process. Clean - Soil, Air, Water, 39: 665-672.

37. Calvo LS, Leclerc JP, Tanguy G, Cames MC, Paternotte G, et al. (2003) An electrocoagulation unit for the purification of soluble oil wastes of high COD. Environ Prog 2: 57-65.

38. Kobya M, Can OT, Bayramoglu M (2003) Treatment of textile wastewaters by electrocoagulation using iron and aluminum electrodes. J Hazard Mater 100 163-178.

39. Phalakornkule C, Polgumhang S, Tongdaung W (2009) Performance of an 
Citation: Ghalwa NMA, Farhat NB (2016) Adsorption of Fenamiphos Pesticide from Aqueous Solutions by Electrocoagulation Using Sacrificial Anodes. J Environ Anal Toxicol 6: 357. doi:10.4172/2161-0525.1000357

Page 8 of 8

Electrocoagulation Process in Treating Direct Dye: Batch and Continuous Upflow Processes. World Academy of Science, Engineering and Technology 3: 9-25.

40. Liu H, Zhao X, Qu JJ (2010) Electrocoagulation in Water Treatment". In: Comninellis C, Chen G (eds) Electrochemistry for the Environment. New York: Springer Science Business Media 245-262.

41. Awad HS, Abu Galwa N (2005) Electrochemical degradation of Acid Blue and Basic Brown dyes on $\mathrm{Pb} / \mathrm{PbO}_{2}$ electrode in the presence of different conductive electrolyte and effect of various operating factors. Chemosphere 6: 1327-1335.

42. Langmuir I (1918) Adsorption of gases on plain surfaces of glass mica platinum. J Am Chem Soc 40: 1361-1403.

43. Freundlich HMF (1906) U“ber die "Adsorption in Lo"sungen. Z Phys Chem 57: 385-470.
44. Weber TW, Chakravarti RK (1974) Pore and Solid Diffusion Models for fixed bed adsorbers. J Am Inst Chem Eng 20: 228-238.

45. Emamjomeh MM, Sivakumar M (2009) Review of pollutants removed by electrocoagulation and electrocoagulation/flotation processes. J Environ Manage 90: 1663-1679.

46. Eslami A, Moradi M, Ghanbari F, Mehdipour F (2013) Decolorization and COD removal from real textile wastewater by chemical and electrochemical Fenton processes: a comparative study. J Environ Health Sci Eng 11: 31.

47. Parga JR, Vazquez V, Moreno H (2009) Thermodynamic Studies of the Arsenic Adsorption on Iron Species Generated by Electrocoagulation. Journal of Metallurgy 2009: 9. 